\title{
Boosting English Competency and Learning Motivation Through the Integrated Approach For Non-English Departments Students
}

\author{
Samsul Amri ${ }^{1}$, Syafrizal ${ }^{2}$ \\ ${ }^{1}$ Universitas Islam Indragiri, Riau, Indonesia, 29211 \\ email:mr.amri85@gmail.com \\ ${ }^{2}$ Universitas Islam Indragiri, Riau, Indonesia, 29211 \\ email: rizaltlp@gmail.com
}

\begin{abstract}
:
At the tertiary level, English as a General Subject supports the main course learning process. The observations show they are not yet proficient enough to use it. It causes indisposed motivation, dearth vocabulary, low learning interest, short time allocation, and others. Therefore, the researchers provide a solution by applying the Integrated Approach. The research objectives are to determine whether the Integrated Approach can improve English competency and learning motivation, how the learners' improvement process, and what factors influence these improvements. It is action research, which was Accounting majoring students as subjects - Islamic University of Indragiri. The data collection process used tests and questionnaires. Furthermore, the results showed an increase in their competence and motivation to learn English before and after applying the Integrated Approach. The improvement process covers several activities; socializing, analyzing, monitoring, guiding, and practicing. Meanwhile, the development affecting factors are internal and external factors such as learning motivation, teaching methods, and the instructors' roles. In conclusion, the Integrated Approach application positively contributes to the learners' learning outcomes and motivation.
\end{abstract}

\section{Keywords: English Competence, Integrated Approach, Learning Motivation}

\section{INTRODUCTION}

As one of the educational institutions, higher education is responsible for providing quality education to produce empowered graduates with high competitiveness and answer the times' challenges. Language competence learning at the tertiary level in Indonesia relates to Act Number 12 in 2012. The learners are expected to acquire linguistic competence. The English class is intended to develop capabilities through something that they may communicate and interact within a specific depth of understanding. It encourages instructional programs throughout essential parts of the matter. They often need to review numerous references in a particular field of research presented in English. Besides, it is frequently included on the world platform to share information.

Furthermore, the English course includes all the skills students must master at a higher level if they want fluent in English. Learning English is given to prepare them to face communication challenges in the professional world. Communication is a prerequisite for human life because, without communication, interaction among humans, individuals, groups, or organizations will not be possible (Nurdianti, 2014 in (Diana, 2018).

Regarding the non-English study program syllabus of the Islamic University of Indragiri Tembilahan-Riau, English is presented during two semesters containing 
five credits. English I covers either English for specific purposes and Basic English, and English II involves English for TOEFL. The learners are known to require adequate English skills to assist them in the employment sector.

In reality, the observations propose that students are not sufficiently trained to employ English language skills. They experience a severe degree of English instructional anxiousness, deficiency of diction, poor encouragement, and short periods of rehearsal. Nevertheless, the subjects learning results is they may show appropriate competence to use English as a communication tool. Also, Juhana (2012) reveals several psychological factors such as fear of making mistakes, embarrassment, a sense of nervousness, lack of confidence, and lack of motivation that prevent students from speaking using language English in class.

One factor that is crucial in learning is motivation. It is an essential issue in education. Bakar (2015) says that learning is not feasible without motivation. It pursues learners to accomplish every assignment, focuses on activity, fulfills their target, and improves learning efficiency. Moreover, it has an impact on the learners' output process. Then it is an ability gained through general practice that is mainly activated by significant others by modeling, communication of aspirations, and direct guidance or socialization (Brophy in Koca, 2016)). Also, (Cook 2008) and (Riswanto \& Aryani, 2017) suggest that it significantly affects educational methods. They claimed that three primary factors affecting information retention: maturity, attitude, and encouragement. Thus, they are inspired to learn everything that will require more astonishing cognitive activities to correctly understand the information.

In addition, Sukmadinata (2003) notes that intrinsic and extrinsic conditions affect motivation. The intrinsic variables include the personality, interests, intellect, and extrinsic variables cover components outside the learner, such as environment, family, school, social, and others. Ryan \& Deci (2000), intrinsic motivation is characterized as the task excitement that a person acquires from everything stimulating and engaging with enthusiasm and curiosity. Extrinsic motivation concerns external advantages [reward].

In the instructional process, an instructor must have the professional skill to employ multiple approaches to achieve the learning outputs. Hence a plan is required to assist them in the integrated, realistic, imaginative, and productive use of language skills and language elements. (HSTW) Annual Staff Development Conference (2013) views that as teachers reach into students' desires and talents to encourage them to grasp academic and professional life subjects that will boost their success prospects. The teachers are increasing the number of strenuous activities that involve students' imagination and problem-solving.

The researchers implemented an Integrated Approach, where English teaching is integrated into a single unit between language skills and components. Jalil \& Elmustian (2006) argue that a concept integrative in language teaching refers to understanding language material as a whole based on language naturally in the language community. Moreover, Juwita et al. (2017) add that the instructors can deliver activity in the education process by integrating the abilities to develop the students' English language competence. Then it attempts to combine numerous contexts and experiences to bring theory to practice in different environments and grasp problems contextually (DeZure et al., 2005).

Harmer in (Ogalo 2011) notes that they employ integrated-skills when the learners study a language. The experts claim language competence integration; the 
language learning procedure includes listening, speaking, reading, and writing as they are combined and inseparable components of language. To cover the four English skills, they may also have chances and tools to participate in meaningful experiences. Compared to the segregatedskill approach, the integrated-skill approach introduces ESL/EFL learners to authentic and naturalistic language. They can obtain an actual image of the English language complexities used for interaction in the integrated-skill approach. It helps educators to monitor their growth at the same time in varied tasks. It is not only the deconstruction of the target language but also facilitates real content learning. Finally, it can be incredibly inspiring for all learners' ages and backgrounds (Oxford, 2001).

Some related findings have been reviewed. Firstly, Iftikhar \& Aslam (2017) carried out an analysis of integrating four English class language skills at the matriculation level. The findings gathered by the conclusion of this quantitative analysis have been portrayed that skills integration occurs either rarely or not, which calls for integrating these abilities and may enhance the learners' learning goals. Secondly, Juwita et al. (2017) researched the EFL teachers' experiences in integrating language skills through 2013 Curriculum implementation. The study reveals that the teachers adopted the scientific Approach process to guarantee that all abilities are integrated into the educational process. The results argue that classroom practices play a significant part in incorporating all English language abilities into the instructional process. Thirdly, Sevy-Biloon (2018) studied integrating EFL skills for authentically teaching specific grammar and vocabulary. This study integrates language skills using communicative activities to learn and practice the present perfect and associated new vocabulary. The results prove that through the different exercises and formal tests, it may be noticed that the students strengthened their comprehension of the present-perfect and enhanced their abilities in listening, reading, writing, speaking, and material. The approach helped them to develop four language abilities authentically.

From the review of related findings above, it can be known that the first study was more complex than this current research because the previous study deals with four language skills; meanwhile, this current study focuses on reading and listening skills only. Furthermore, the second study focused on combining the Scientific Approach with Integrated Approach, especially for secondary schools. This study does not combine with other approaches, and it was also carried out at the tertiary level. The third study also had a distinct focus on implementing Integrated Approach, which was on language usage and vocabulary. It is different from the current study's focus. The studies reviews indicate that the Integrated Approach has been implemented in various issues, beneficial in the teaching and learning process.

The current study delivers some aims; to determine whether the Integrated Approach improves the students' English competence and learning motivation, finds out how it increases the results, and determines the influencing factors of enhancement. Hopefully, this investigation enables to hand over new results on implementing the Integrated Approach especially for university level, show the instructional process in applying it, and capture the affecting variables of the instructional process outcomes.

\section{METHOD}

It is Action research. Anna et al. (2006) define that action research is a selfreflective study of participants' social and education contexts (the teachers and the students). Furthermore, classroom behavior 
analysis is carried out through a wellorganized, which involves a plan, action, observation, and reflection. It was conducted for Accounting major students at the Islamic University of Indragiri Tembilahan, Riau, 37 students. In collecting data, the researchers used tests and questionnaires. The research tool test was also carried out to get accurate results using the validity test. In this case, the researchers use content validity by seeing whether the test items are by the existing indicators (Azwar, 2013). Then in analyzing the data, they utilized quantitative and qualitative analyses.

\section{FINDINGS AND DISCUSSION}

\section{Test Outcomes}

During eight sessions, this study was rolled out. At this initial meeting, the researchers introduced all the things related to the courses and conducted a pre-test to assess the learners' primary competence. It seemed that the results were unsatisfactory since the material intends to the standardized test of TOEFL. Thus, the researchers applied an Integrated Approach as a reasonable approach to strengthening their competence to learn English.

Starting in the second meeting, they employed an Integrated Approach in the instructional process. The central topic in this meeting is listening skills with the theme of short conversations. Five subindicators take place; listening to the restatement, synonyms, state, negative expression, and agreement. Then the team combined listening comprehension and vocabulary mastery. The researchers listened to the audio. The test results were as below:

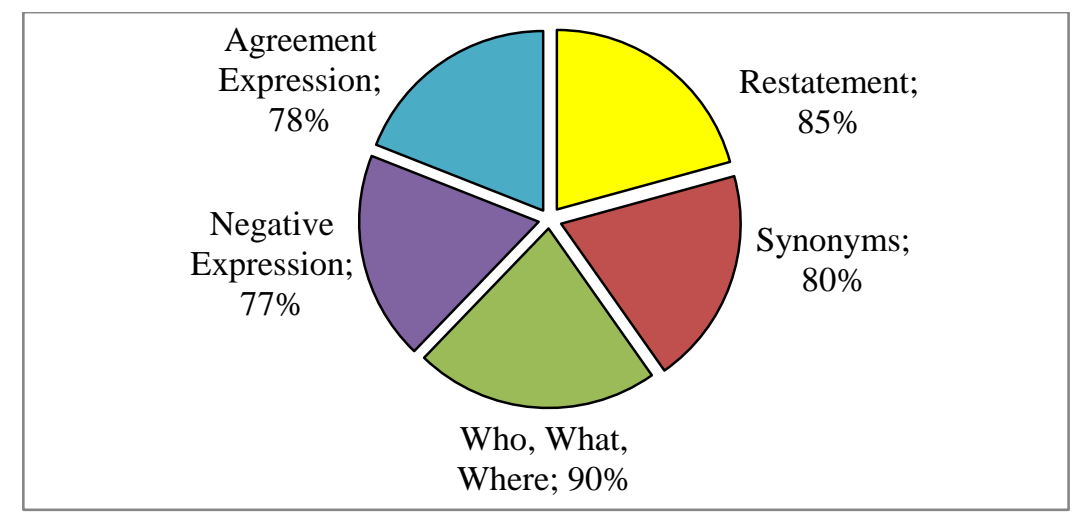

Figure 1 Students' Ability in the Short Dialogue

It is known five skills provided related to the actor (who), the object (what), and the state (where) obtained the highest score by a percentage of $90 \%$. It was followed by restatement ability with the percentage $85 \%$, the $80 \%$ was for a listening synonym, $78 \%$ was for agreement, and the lowest score, $77 \%$, belonged to negative expression. Even so, these results need to improve.

The next meeting was kept going the earlier material, the sub-theme of short dialogue. Four traits have been trained; listening to suggestions, surprises, wishes, idioms, and uncertainty. The investigator incorporated the core competencies: listening, diction, and pronunciation. They rechecked what they explained at the latest sessions. Then by showing the audio to the learners, they deliver them with current competencies.

In the earlier session, the investigators challenged the learners to articulate the words they learned from the recordings. Some of them were still reluctant in articulating the terms since they were ashamed of making misarticulated. Therefore, their task is to integrate between 
properly articulate and their diction abilities. The term Know is one example; it was not entirely accurate on how to utter it. Sometimes it is uttered /no:/ or /nau/, but /nov/ is the right one. Other vocabulary is the term everything that has been common for them; they may automatically listen to it when the word is heard in the recording.
The pronunciation, nevertheless, is not completely correct. The term everything is often uttered /evriting/; it should be / 'evrigiy/. Hence, they either possess wide and diverse diction or encourage them to articulate them properly. As evaluation results of this session were as follows:

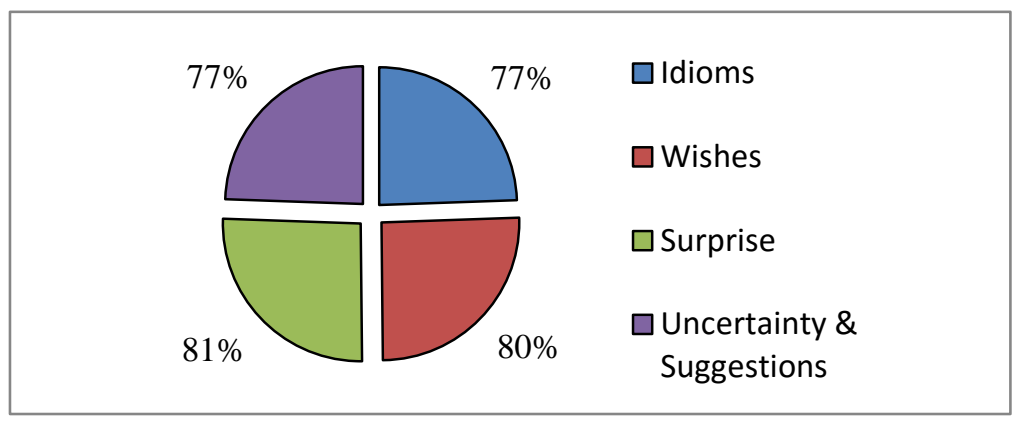

Figure 2 Students' Competence in the short dialogue

It reveals the skills in answering Surprise's expression questions get the highest score with a percentage of $81 \%$, listening to wishes obtained a percentage of $80 \%$, which are categorized as an excellent level. In other words, the learners have sufficient skill in answering the questions. Furthermore, listening to idioms and suggestions skills are considered quite difficult for them. The percentage proves it reaches $77 \%$.

The data collection process was continued to the next session; the core topic was still about listening proficiency, which are two sub-topics: Long Conversation and Monologues. The researchers' integrated listening, diction, pronunciation, and elemental composition. They verified the previous topics before presenting the topics in this session. After that, they outlined the sense and how to respond to the questions of Long Conversation and Monologues. It was not so different from the earlier sessions; they listened to audio given.

They checked what terms the learners had after hearing the audio many times.
Thus they replied by recalling the terms. They gave the correct forms if the pronunciation is not right. They were then challenged to write down as many words as they have learned on a piece of paper and note down the terms they received on the board. Then they were split into classes, discussed and given final insights of the recordings they had listened to, and then answered the queries. This method incorporates language proficiency and language elements. The assessment outcomes at this session are as follows: 


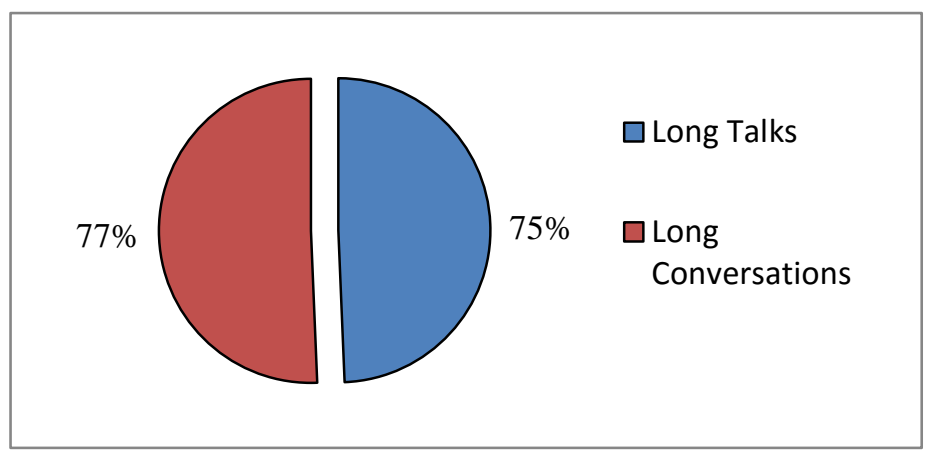

Figure 3 Students' Competence in Long Conversation and Long Talks

It displays the learners' comprehension in listening to long conversations and monologues. Their ability for long conversation gained a score of $77 \%$, and monologues obtained $75 \%$. The findings are not yet optimal. Therefore, it hopes that they can gain better results in the future.

Also, the researchers sustained to the next implementation; the primary subject matter was reading comprehension. It started from the reading understanding for the TOEFL. After that, it continues its tasks and abilities required for passing the reading tests. It is concerned with queries about the main idea and how to solve them. They kept going to extend the integrated approach by integrating reading, listening, diction, and pronunciation capabilities.

An essential feature of excellent reading skills is to locate the main idea of a text. It is possible to explicitly or indirectly explain the main idea. Commonly, it notices in the initial sentence of the paragraphs. However, it can be identified in other sentences in a paragraph (Philips, 2001). The researchers allowed them to recite the paragraph loudly. It requires testing the pronunciation aspect. They offered the proper pronunciation if there is a mistaken articulation. For instance, a learner articulated the term condor by uttering /kondor/; it is not proper enough because it is pronounced by /'kpnds:(r)/ or /'ka:ndo:r/. Indirectly, this technique helps them to strengthen their skill by listening to proper pronunciation. Next, they were asked to concentrate on the initial sentences of the provided text. It assists them in getting the main idea in the text. To enhance their skill, it rolled out on various reading resources. The quiz results can be seen.

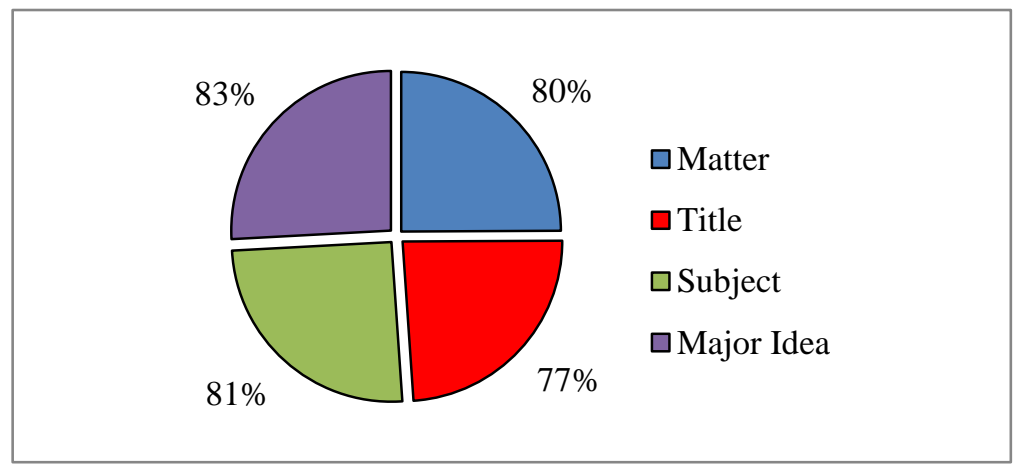

Figure 4 Students' Competence in Getting Main Idea

| ELT-Lectura: Studies and Perspectives in English Language Teaching Copyright@ 2021 Samsul Amri, Syafrizal 
The data informs the learners' competence in locating main ideas in the texts. Four indicators include; matter, subject, title, and major idea. It illustrates that they can find the texts major ideas; it proves a percentage of $83 \%$. Finding subjects and matters of the passages follows with the percentage $81 \%$ and $80 \%$. Those results are classified as an outstanding level. Getting the text title was at an acceptable level by a percentage of $77 \%$. In brief, their ability to get the main idea is satisfying. However, they should improve to gain better learning outcomes.

Moreover, other critical sub-materials were getting stated and unstated details and vocabulary in the reading passages. They merged some language activities which cover reading, listening, diction, and articulation. They identified the abilities to resolve reading inquiries related to stated and unstated information. They challenged them to read the passages to correct mispronouncing. It addressed to enhance

The researchers kept gathering the data by implementing the Integrated Approach. In this case, there are two significant sub-topics; identifying references and inferences. English has a way of referring to objects in order to avoid boredom from repeating words using reference words (Syamsuddin, 2005). Furthermore, Sharpe (2009) argues that this kind of query asks you to recognize a particular word (pronoun) or phrase in the passage that deals with a word. The authors employ some pronouns throughout the text. Two kinds of pronouns that have been widely used in varied texts are 1) Personal pronouns, for instance, I, you, we, they, she, he, it, me, them, her, his, and 2) demonstrative pronouns; this, that, these, those.

In enhancing the skills, the researchers integrated language skills and components. They challenged the learners to read the passage provided, such as. vocabulary and pronunciation mastery properly. It also develops their listening abilities from English vocabulary stated by other learners.

Philips (2001) argues that you should first locate the keywords and identify these terms in the passages to resolve queries concerning stated and unstated details. An illustration of a query is "The oldest flutes, according to the passage..." from the example, it finds that the "oldest flutes" were the keywords identified. They challenged them to locate the terms and read some statements regarding these keywords a few times.

Besides, they rolled out similar practices while posing queries about vocabulary by integrating reading and vocabulary proficiency. To develop the learners in these skills, they conducted the tasks on various reading passages. In this case, they integrated both reading and vocabulary proficiency.

"The full moon that occurs nearest the equinox of the Sun has become known as the Harvest Moon. It is a bright moon which allows farmers to work late into the night for several nights; they can work when the moon is at its brightest to bring in the fall harvest..."

They needed to identify pronouns. Two pronouns are noticed in the text (it and they). They identified the pronouns to develop their English sentence structure understanding. For instance, It refers to the word Harvest Moon, and the pronoun they refers to the word farmers. This integrated practice encourages them to grasp the reading material and strengthen their vocabulary knowledge and basic grammar.

The coming up task is to develop the ability to determine inference. Sometimes, authors do not present ideas explicitly in the text, but readers may interpret the meaning 
implicitly from what the author intends to transmit (Sharpe, 2009). To gain conclusions, it relates to the observation process or the readers' prior information. They sought to follow the integrated approach to develop these skills by merging reading and vocabulary proficiency. They trained them to be familiar with the questions of these skills. They directed them to recognize the multiple choices answer one by one and ensure they are in the texts. They seek keywords in the question. If they discovered them in the texts, they read some sentences regarding the keywords. The test results are in the following:

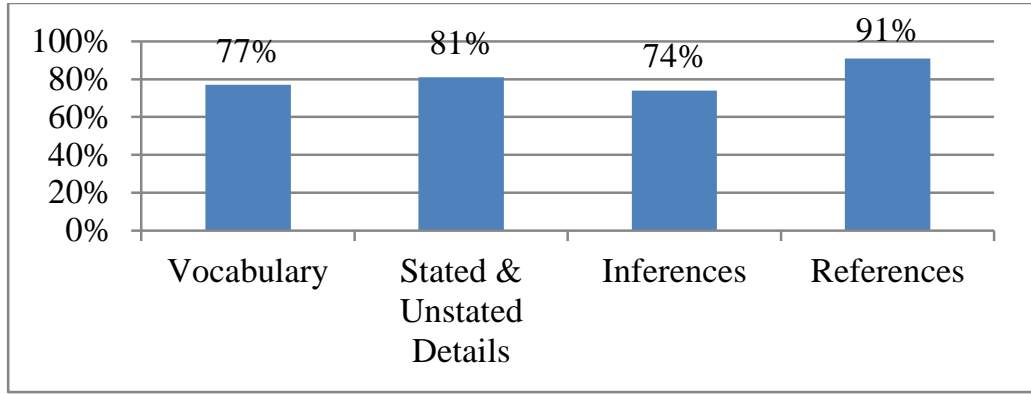

Figure 6 Students' Competencies in Finding Stated, Unstated Details and Vocabulary, References, and Inferences

The data display the learners' ability to identify indirect or direct details, which obtain $81 \%$. Meanwhile, in identifying vocabulary mastery was rating $77 \%$. It should categorize as positive outcomes. Also, it offers the data of their capacity in identifying references and inferences in the reading passages. These findings suggest that in seeking references in the text, they gained $91 \%$ proportion.
Meanwhile, it is not easy to infer details in the text, verified by the $74 \%$ result. This rating is the weakest score compared with the skills of other metrics. It assumes that their ability in reading skills is varied.

The learners' improvements in English competence during the treatments given are as follows:

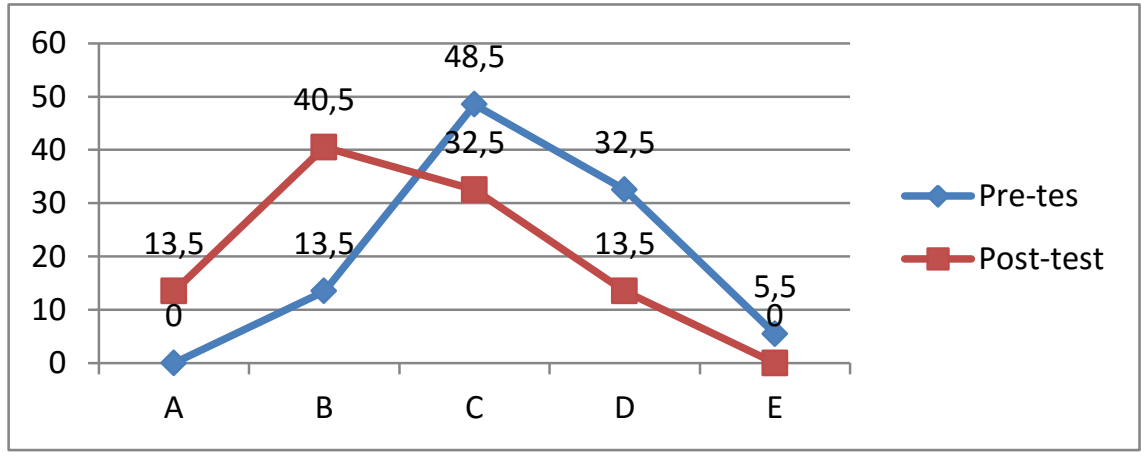

Figure 7 The Learners' English Competence Improvement

It displays an increase in the learners' implementing the Integrative Approach. It English skills before and after illustrates no learners who reached an | ELT-Lectura: Studies and Perspectives in English Language Teaching Copyright@ 2021 Samsul Amri, Syafrizal 
excellent level (A), but there were $13.5 \%$ of them at this level after the Integrated Approach application. Furthermore, at an acceptable level (B), the pre-test results showed that $13.5 \%$ of them were at this level. The improvement can be seen that $40.5 \%$ of them reach this level on their post-test scores. Then, at the sufficient ability level (C), the pre-test score showed $48.5 \%$ of students were at this ability, and there was a decrease in the percentage; $32.5 \%$ of them were at this ability in posttest results. It shows that there is an improvement in their ability. Likewise, at the low level of ability (D), the pre-test scores showed that $32.5 \%$ of students were at this level, but there was an increase in the post-test scores with $13.5 \%$ of students. It also occurs at the deficient ability level (E), which shows that there are still $5.5 \%$ of students at this level in the pre-test, but there are no learners who get this score at the post-test. This description provides evidence that the Integrated Approach application contributes to the learners' English competence improvement.

\section{Questionnaire Outcomes}

The researchers also used a questionnaire to determine the learners' English learning motivation to get accurate data. As discussed in the theoretical study, there are five learning motivation indicators: learning persistence, resilience in facing difficulties, learning curiosity and focus, academic performance, and learning independence (Riduwan, 2005).

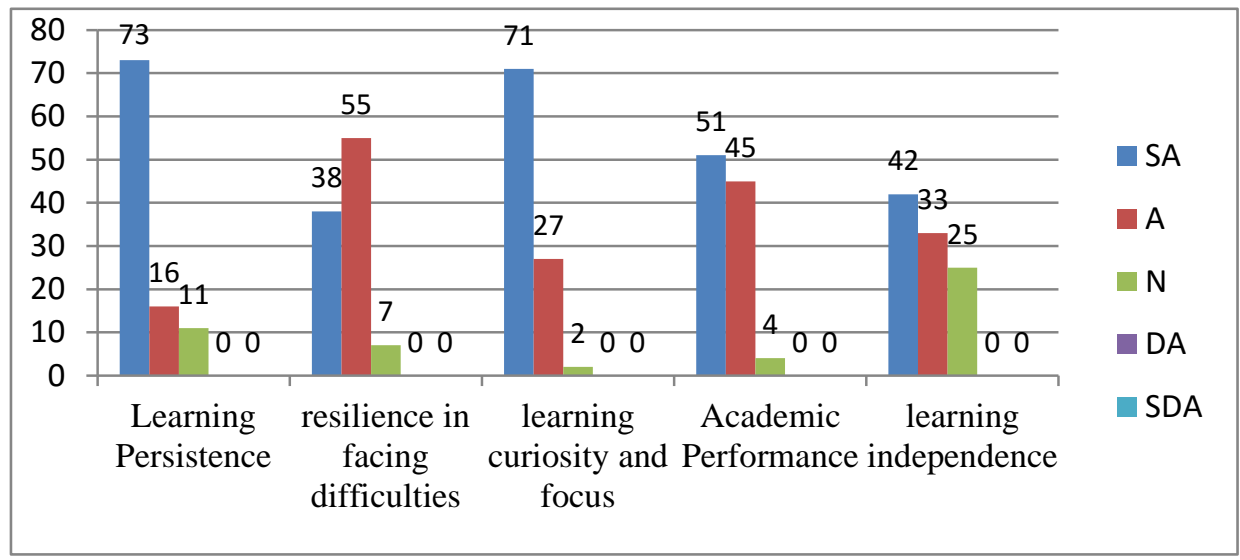

Figure 8 the Learners' Learning Motivation

The information indicates the learners' motivation in each metric during the instructional activities. Learning persistence is the first learning encouragement. It composes of three submetrics; attending the lectures, joining class activities, and studying at home. The learners show that they have positive motivation for learning persistence in learning. It proves that $73 \%$ of them ultimately agreed, then $16 \%$ agreed, and $11 \%$ were neutral in their answers. The second measure concerns flexibility in coping difficulties. It includes two subpoints: attitude to adversity and problemsolving effort. It illustrates that $38 \%$ of respondents fully agreed, $55 \%$ accepted, and $7 \%$ offered neutral answers to the items. The next indicator is curiosity and focuses on studying, including two points: attending lectures manner and attending lectures enthusiasm. It reveals that in learning, they have significant curiosity and focus. It shows that $71 \%$ of them agree 
entirely with their responses, and $27 \%$ of them decided to agree, whereas only $2 \%$ reacted to the issues neutrally. Academic performance is the other indicator. It contains two major points; desire for achievement and qualification outcomes. The findings indicate that more than $50 \%$ of them strongly agreed, $45 \%$ agreed, and only $4 \%$ were neutral. Independent learning is the last criterion. It refers to how autonomous the learners in studying. Two significant cases include; the lecture task fulfillment and opportunities outside the hours of class. Data show that $42 \%$ reacted strongly, $33 \%$ agreed, and $25 \%$ neutral to the situation. The data also tells us that no one has decided to disputes and completely disagrees with the statements. To summarize, they are highly motivated in learning. It implies that the teaching process implemented by the researchers pertains beneficially to their learning motivation.

\section{The Learners' Learning Development Process}

The researchers analyzed the qualitative and quantitative details, including determining the process of the learners' improvement. After analyzing the outcomes, they claimed an improvement in the learners' English knowledge by applying Integrated Approach activities.

Several tasks were included in the activities, such as socializing, analyzing, monitoring, guiding, and practicing. Firstly, socializing covers the phase where the researchers outlined the selected teaching materials. It aims at helping learners with a comprehensive understanding of the topic. Secondly, analyzing includes the activities of review of the topic given in the prior meetings. They checked how deep their understanding was. Thirdly, monitoring includes the sequence of controlling their activities during the teaching process. It was carried out to ascertain whether they may perform the instructional duties well and had learning problems. Then they undertook the guiding strategy to aid those who had learning problems. They can ask about learning challenges that included sufficient vocabulary, sentence structure, and other problems. This strategy, thus, develops their English competence more productively. Another successful approach is practicing. They implemented the Integrated Approach process by integrating language abilities or components. This process was conducted during the execution of the study. In summary, multiple mechanisms were methodically implemented to enhance the competence and motivation of the respondents. Consequently, they may be motivated more and gain better results.

\section{The Influencing Factors of the Learners' Learning Development}

The individual learning achievement results from the interaction between the various factors that influence it, both internal and external. In this current study, the researchers found some factors that affect their learning development. They analyzed from both the qualitative and quantitative data.

Some factors affect their learning development. Motivation plays a vital role in the learning process. In this research, it is noted as one cause that influenced their English capability development. Their attitude supports it. They enable to provide positive responses when questioned by the researchers, and they were enthusiastic and interested in giving views or ideas. It can provide a meaningful effect on their academic results. These results relate to some studies' findings. Alkis (2015) views that educational researchers and practitioners argue that it is one of the most significant variables in achieving continuous achievement. Baron and Donn (2000) in (Bakar, 2015) claim that some characters indicate learners with great motivation, such as initiative, diligence, and active learning, not comfortable to satisfy, punctual and disciplined, always trying to learn with the best result. Moreover, it is 
supported by the opened questionnaire results for the items "Are you more motivated to learn English by the lecturers' way of teaching? Why?" response such as:

"Yes. It is more motivated because what is taught by the lecturers is easier to understand and easier to capture what is being thought and carried out now. "

Furthermore, the teaching method also influences their academic development. In this study, the researchers implemented the Integrated Approach as learning problem-solving. Various activities were brought to create a comfortable atmosphere in the instructional process. These results are proven by the questionnaire responses on the item "Does the method used by the lecturer in English lectures make you more confident? Why?" a learner responded:

"Mr. Amri, every time he explained, all the students participated in the explanation. All students will be tested one by one to answer or give examples as he explained. Students will be made to think to find examples or the correct answer. If it's wrong Mr. Amri will explain where the error lies and how to correct it. Mr. Amri also explained that the material was very simple and straightforward so I could easily understand what he was conveying. I am happy with the method Mr. Amri, because I quickly and easily understood the material and became fond of English...."

It is relevant to Prihatini's view (2017) that the learning method functions to support the learning effectiveness process; therefore, it can increase interest in learning and make it easier for students to get satisfying learning results. Nasution (2017) found that the learning methods and students' learning outcomes were in the medium category; it indicates a strong relationship between learning methods and students' learning outcomes. Thus it can be said that the use of appropriate learning methods can improve their learning outcomes. In sum up, the teaching method contributes better improvement to their academic results.

Moreover, another affecting variable is the lecturers' task. During the instructional process, they also attempted to control and guide the learners. It makes them more enjoyable; they were not afraid of asking about their learning difficulties. It can be proven by their responses to the question, "Do lecturers always assist students if they get learning difficulties? Why? (You may provide examples of the lecturers' activities in assisting you, if any)." Some answers are below:

"Yes, the lecturer will explain again if there are students who do not understand. And the lecturer provides an explanation in easy to understand language."

Related theories also support the findings, such as Saroyan et al. (2009) in (Mupa \& Isaac Chinooneka, 2015) pointed out those four insights about successful teaching. They have the experience, plan and teaching management, facilitate learning, and help students develop. Consequently, they can learn autonomously. Then Ulug et al. (2011) view that the teacher is one of the external variables. In education and learning, the teacher is the most significant element. Therefore, teachers implicitly influence their learning results. Therefore, the lecturers' role in the instructional process positively impacts the learners' learning performance.

\section{CONCLUSION}

This study produced some findings. Firstly, the Integrated Approach contributes positively to the learners' competence and motivation in learning English. The test results prove that their percentage in 
learning English improves by comparing pre-test and post-test scores. The questionnaire results also support that they have a positive attitude toward learning during the instructional process. Secondly, their learning improvement causes some activities to include socializing, analyzing, monitoring, guiding, and practicing. Those make them more relaxed in learning and solve their learning challenges. Thirdly, their learning development is influenced by both intrinsic and extrinsic factors, which covers learners' motivation, teaching method, and lecturers' tasks. Those findings are strengthened by the findings of some studies and empirical data.

Eventually, this current study leads to the Integrated Approach's execution model, which can be the primary component in improving EFL learners' English competence and learning motivation. To see the critical role of lecturers in enhancing them, there are several pedagogical implications for advancing designs and

\section{REFERENCES}

Alkis, N. (2015). The Influence of Personality Traits, Motivation, and Persuasion Principles on Academic Performance. The Middle East Technical University.

Anna, Uhl Chamot, et al. (2006). Conducting Action Research in the Foreign Language Classroom. National Capital Language Resource Center.

Azwar, S. (2013). Tes Prestasi: Fungsi dan Pengembangan Pengukuran Prestasi Belajar. Pustaka Pelajar.

Bakar, R. (2015). The Effect of Learning Motivation on Students' Productive Competencies in Vocational High School, West Sumatra. International Journal of Asian Science, 4(6), 722732.

Cook, V. (2008). Second Language materials for learners at the tertiary level. It has been stated that by improving their English competencies and learning motivation, educators hold a part in promoting learners. Consequently, it is suggested that they possess a grasp of the importance of learners' English skills and the learning encouragement in the language classroom and how to improve it. They can also identify and analyze their learners' learning habits to deliver optimal instructional results. Various insights are then portrayed to prospective scientists. It is suggested that future researchers conduct other experiments employing various research methodology to provide mixed results. Moreover, it is recommended to investigate the influence of the Integrated Approach on language usage, as an advance of this research, which adjusts primarily on listening and reading comprehension. A final comment recommends that the Integrated Approach be chosen as an alternative teaching and learning activity.

Learning and Language Teaching (Fourt Edit). Hodder Education, an Hachette UK Company.

DeZure, D., Babb, M., and Waldmann, S. (2005). Integrative learning nationwide: emerging themes and practices'. AAC\&U, Summer/Fall, 2528. https://www.aacu.org/publicationsresearch/periodicals/integrativelearning-nationwide-emerging-themesand-practices

Diana, L. (2018). Hambatan Pembelajaran Bahasa Inggris Mahasiswa Fakultas Pertanian Universitas Pembangunan Nasional Veteran Jawa Timur. Berkala Ilmiah Agribisnis AGRIDEVINA, 7(1), 93-101.

High Schools That Work (HSTW) Annual Staff Development Conference. (2013). Instructional Strategies Motivate and Engage Students in Deeper Learning. Sreb, April 2003, 18. 
Iftikhar, Saira., \& Aslam, Arooj. (2017). Integration of Four Language Skills in English Class. Scientific Journal of Management and Social Sciences (SCIMASS), I(I), 45-53. www.scimass.com

Jalil, A. E. (2006). Pendidikan Bahasa Indonesia di Kelas-kelas Rendah sekolah Dasar. Unri Press.

Juhana. (2012). Psychological Factors That Hinder Students from Speaking in English Class (A Case Study in a Senior High School in South Tangerang, Banten, Indonesia). Journal of Education and Practice, 3(12), 100-110. www.iiste.org

Juwita, Mariza; Wachyuni, Sri; Sulistyo, Urip; Habibi, Akhmad; Amri, Y. (2017). EFL Teachers experiences in Integrating Language Skills through Kurikulum 2013 Implementation. International Conference on Language Teaching and Education (ICoLTE).

Koca, F. (2016). Motivation to Learn and Teacher-Student Relationship. Journal of International Education and Leadership, 6(2).

Mupa, P., \& Isaac Chinooneka, T. (2015). Factors contributing to ineffective teaching and learning in primary schools: Why are schools in decadence? Journal of Education and Practice, 6(19), 125-132. https://files.eric.ed.gov/fulltext/EJ1079 543.pdf\%0Ahttp://search.ebscohost.co $\mathrm{m} /$ login .aspx?direct $=$ true $\& \mathrm{db}=$ eric $\& \mathrm{~A}$ $\mathrm{N}=\mathrm{EJ} 1079543 \&$ site $=$ ehost-live

Nasution, M. K. (2017). Penggunaan Metode Pembelajaran Dalam Peningkatan Hasil Belajar Siswa. Studia Didaktika: Jurnal Ilmiah Bidang Pendidikan, 11(1), 9-16. jurnal.uinbanten.ac.id

Ogalo, M. O. (2011). Teaching Techniques that Enhance Integration in the Development of English Language Skills in Secondary Schools in Gatundu District, Kenya.

Oxford. (2001). Integrated skills in ESL/EFL classroom. Oxford English Dictionary, 2010(07/07), http://dictionary.oed.com/. http://dictionary.oed.com

Philips, D. (2001). Longman Complete Course for the TOEFL Test. A Pearson Education Company.

Prihatini, E. (2017). Pengaruh Metode Pembelajaran Dan Minat. Formatif: Jurnal Ilmiah Pendidikan MIPA, 7(2), 174.

Riduwan. (2005). Belajar Mudah Penelitian untuk Guru, Karyawan, dan Peneliti Pemula. Alfabeta.

Riswanto, A., \& Aryani, S. (2017). Learning motivation and student achievement: description analysis and relationships both. COUNS-EDU: The International Journal of Counseling and Education, 2(1), 42. https://doi.org/10.23916/00201702601 0

Ryan, R. M., \& Deci, E. L. (2000). Intrinsic and Extrinsic Motivations: Classic Definitions and New Directions. Contemporary Educational Psychology, 25(1), 54-67. https://doi.org/10.1006/ceps.1999.102 0

Sevy-Biloon, J. (2018). Integrating EFL skills for authentically teaching specific grammar and vocabulary. Studies in English Language and Education, 5(2), 175-184. https://doi.org/10.24815/siele.v5i2.970 5

Sharpe, P. (2009). Baron's: The Leader in Test Preparation, Practice Exercise 
for the TOEFL. The Ohio State University.

Sukmadinata, N. . (2003). Landansan Psikologi Proses Pendidikan. Remaja Rosdakarya.

Syamsuddin, A. M. (2005). Strategi Menguasai Reading Comprehension TOEFL. LINGUA.

Ulug, M., Ozden, M. S., \& Eryilmaz, A. (2011). The effects of teachers' attitudes on students' personality and performance. Procedia - Social and Behavioral Sciences, 30, 738-742. https://doi.org/10.1016/j.sbspro.2011.1 0.144 